
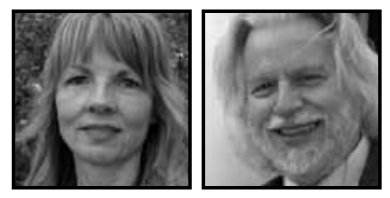

\title{
The Promise of Creativity
}

\author{
Maxine E. Sprague and Jim Parsons, University of Alberta
}

\begin{abstract}
In this paper, the authors discuss creativity and the impact it might have on teaching and learning. The authors believe that imaginative play, at all ages, helps all people (children especially) create healthy environments and spaces that expand their learning. The authors contend that teaching for imagination-which asks little more than creating and trusting an ecological space that engenders it-seldom is considered a priority. Given the emphasis on creativity in the real world and the virtual digital world, the authors believe it is important to add to the body of knowledge through continued research in this field.
\end{abstract}

\section{The Promise of Creativity}

"But the quality of the imagination is to flow, and not to freeze."

(Emerson, Ferguson, \& Carr, 1987, p. 238)

In the summer of my sixth year a great expectation arose within me; something overwhelming was pending. I was up each morning at dawn, rushed to the top of Dorchester Hill, a treeless knoll of grass and boulders, to await the sun, my heart pounding. A kind of numinous expectancy loomed everywhere about and within me. A precise shift of brain function was afoot; my biological system was preparing to shift my awareness from the pre-logical operations of the child to the operational logic of later childhood, and an awesome new dimension of life was ready to unfold. Instead, I was put in school that fall. All year I sat at that desk, stunned, wondering at such a fate, thinking over and over: something was supposed to happen, and it wasn't this. (Pearce, 1985, p. xiii) 


\section{A Need for Creativity}

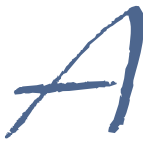

s a child, Pearce was eager to learn. Sadly, school didn't match his burning desire. Implicit in Pearce's writing is the critical point: if we want children to sustain an interest in learning, the desire to learn must come from within each learner.

In The Human Odyssey: Navigating the Twelve Stages of Life, Thomas Armstrong (2007) recounts the story of the Bronte family. In 1826, Reverend Patrick Bronte brought a gift of 12 wounded toy soldiers to his 9-year old son. The gift expanded beyond the father's imagination. With Tolkien-like fervor, the four children-Charlotte, Branwell, Emily, and Anne-created imaginary worlds, even writing and editing a magazine that outlined the languages and social structures of these worlds and developing systems of government for their imagined realm. The vitality of these worlds came alive in novels; Charlotte's Jane Eyre, Emily's Wuthering Heights, and Anne's The Tenant of Wildfell Hall. From a gift of twelve wounded soldiers, the children's imagination created a world that expanded as they aged.

Our paper is about creativity's impact on teaching and learning. We believe children have an innate desire to learn. We believe imaginative play, at all ages, helps children create healthy environments. As teachers, we are fundamentally interested in schools and learning. Regrettably, we see school structures that crush children's imagination. Schools, our primary institution for shaping individual and community values, are also the site for shaping a younger generation towards the citizens we wish they might become. Children are taught by the formal and informal content and pedagogy of school.

Certainly some have envisioned investing schools with creativity. As reminded by an anonymous reviewer of this article, John Dewey's early 20th century child-centered learning included creative curricula, which Waldorf and Montessori schools used to build experiential learning models. Creative curricula has knocked on the door of North America's mainstream educational system-the Open Classrooms of the 1960s and 1970s-promoted by those who value alternative educational approaches. As well, integration models that teach subjects through and with the arts can improve student engagement, help students see themselves as creative, and positively impact standardized test scores (Walker, Tabone, \&Weltsek, 2011). This said, today's schools (Leyva, 2009) seem closer to Social Darwinism, where essentialist ideals of meritocracy, selfishness, and competition ground curriculum policy such as George Bush's neoliberal No Child Left Behind Act (NCLB). 
Not all curriculum policy is as blatant as NCLB. Longstreet and Shane (1993) note a hidden curriculum, which includes the learning children derive from the "nature and organizational design of the public school, as well as from the behaviors and attitudes of teachers and administrators" (p. 46). Eisner's (1994) null curriculum includes what we do not teach in schools and, by not teaching it, tell students what is important. Eisner argues that ignoring something is far from neutral. Implicit student and teacher consequences exist for what is not taught and what processes are not used. This no-place, we believe, is where creativity lives in today's schools-part of a null curriculum.

Judged by our schools' actions, we prize literacy. In essence, every school subject is a vocabulary lesson; students learn the lexicon of a subject but little about the life processes that ground these subjects. School knowledge is narrower than it need be, failing to encompass imagination and play-the two horsemen of creativity. We contend that teaching for imagination-which asks little more than creating a space that engenders it-seldom is a priority. Instead, classrooms become artificial contexts that pull children away from the "real world" - a dynamic, diverse, and disorderly space.

The real world is dynamic. Schools, in comparison, are often decontextualized from engaged, practical, real-world living actions. The gulf between decontextualized school cultures and problems that confound society has expanded to the point where few children believe school is relevant. Armstrong (2007), ironically, believes school helps children whose jobs will be to sit inertly at desks, expending minute amounts of mental imaginative energy-a dystopian work depiction found in movies like Office Space.

The real world is diverse. School curriculum, in comparison, seems to knead diversity from children. Standardized exams, at their soulless heart, are founded on compliance to standards that, by their nature, limit, fear, and work to remove diversity from children in almost xenophobic ways. In short, school doesn't prize creativity: it seeks similarity and compliance to standards.

For Armstrong (2007), school children learn NOT to question too much, NOT to think too differently from their peers, and NOT to be too creative. Instead, they learn to submit to authority, follow bureaucratic conventions, compete against their neighbors, see the world as dog-eat-dog, sit still, and keep their minds from wandering off topic. Educational anthropologist Jules Henry (1964) sees schools as our most conservative cultural institution, a place where we surrender our babies to the 
demands of competitive consumer society, where they learn to sit bored for hours as they are pigeonholed into winners and losers without violently rebelling. Henry believes the hidden curriculum is to face absurdity with patience-a skill needed in work.

The real world is disorderly. Schools, in comparison, are structured, organized, and predictable. Children enter and leave on predetermined schedules based on birthdates. They move through semesters, grades, and outcomes in scaffold-like sequence, driven by timelines. School is arbitrarily divided into distinct subjects with minutes punctuated by bells. Weeks and months become reporting periods, where final grades are allotted. Creativity seldom blossoms in rigid and contained frameworks-unless it is creative revolution, which carries consequences. Scientific creativity expert Sawyer (2006) notes, lived creativity requires space and time, flexibility, work, and collaboration.

\section{Considering Creativity}

Creativity's potential has not always been ignored. Joy P. Guilford's 1950 American Psychological Association presidential address called on colleagues to increase creativity research. At the same time, others recognized that creativity differed from intelligence (Cropley \& Cropley, 2009; Kaufman, 2009; Sawyer, 2006). Creativity research expanded from psychology to sociology, anthropology, history (Sawyer, 2006), and neuroscience (Kaufman, 2009). To date, a body of research (Kaufman, 2009; Plucker, Beghetto, \& Dow, 2004; Runco, 2007; Sawyer, 2006) indicates that creativity is complex and diverse.

We are responding to Guilford's call to consider creativity in schools. In this article, we discuss creativity with respect to individuals, the environment, and schooling. Our work briefly overviews creativity literature to better understand research findings within school contexts, and to invite educators to consider how creativity might be wisely interjected into classrooms.

Guilford (1967) believed creativity was a natural and valuable societal resource (Runco, 2007) and proposed two kinds of thinking-convergent (single solutions, closed-ended tasks) and divergent (multiple solutions, open-ended tasks). He links divergent thinking to creativity; but suggests, "creative potential is very complex" (p. 169) and cannot be attributed solely to divergent thinking. 
The first 20-30 years of creativity research followed individualist approaches consistent with prevailing psychological theories and a cultural bias toward European high art genres (Sawyer, 2006). Sawyer (2010) supports a contextual approach more accepted during the last 30-40 years, which calls for socio-cultural and constructivist perspectives of creativity. We suggest a third alternative-an ecological model discussed later in this paper-that more effectively infuses creativity into children's lives.

A major challenge for creativity researchers is agreeing on a definition. Plucker et al. (2004) reviewed 90 articles on creativity, noting that only 38 percent explicitly defined creativity. Definitions generally fall into two categories referred to as Big-C creativity (socially valued products) and little-c creativity (everyday activities) (Kaufman, 2009; Sawyer, 2006). Little-c creativity suggests that anyone can create ideas or products; Big-C creativity is defined by two characteristics: (a) the product or idea is unique and (b) appropriate to the situation-however appropriate is defined.

There is general agreement that creativity, regardless of age of entry into a particular field, requires ten years' experience in that domain (Kaufman, 2009; Sawyer, 2006). Time and experiences are needed to develop expertise through learning domain-specific tools, conventions, techniques, languages, and instruments. Creativity might also follow the 10,000-Hour rule (Swedish psychologist Anders Ericsson's theory) that success arrives when someone spends 10,000 hours practicing (Gladwell, 2008).

Plucker et al. (2004) suggest that "creativity mythologies" abound: only certain individuals, commonly portrayed as loners, are born creative; creativity intertwines with negative social and psychological thinking; creativity is a "soft" concept; and groups are more creatively productive than individuals. Believing a definition would benefit researchers and educators, Plucker and colleagues propose: "Creativity is the interaction among aptitude, process, and environment by which an individual or group produces a perceptible product that is both novel and useful as defined within a social context" (p. 90).

Although debate surrounding creativity mythologies persist, many researchers do not equate creativity with oddity. Kaufman (2009) notes that creativity involves ideas, products, and processes found within individuals, groups, or even society. Sawyer (2006) adds that creativity can be culturally, socially, and historically situated. Egan (2005) suggests that creativity can be defined on a continuum "from a creative adaptation to a dynamic alteration" (p. 162). In short, creativity can be discovered in everyone. 


\section{Exploring the Assessment of Creativity}

Connecting creativity to curriculum can be difficult, because learning is usually assessed corporately; everyone writes the same exam or does the same assignment, and individuals are graded against each other. Such assessment homogenizes production. Combining this tradition with the lack of an agreed-upon creativity definition presents assessment challenges for educators. In keeping with our Western educational tradition, if one believes creativity is crucial to a student's curricular experience, it must be assessed. However, there is irony in assessing creativity-if it is an individual attribute- - using corporate testing models. As a result, assessing creativity becomes complex.

E. Paul Torrance, perhaps the educator most connected to creativity, separated himself from the 1950s view that creativity was fixed at birth by developing creativity tests and exploring how creativity might be taught (Kaufman, 2009; Sawyer, 2006). The Torrance Tests of Creative Thinking (TTCT) are based on Guilford's FFOE model of divergent thinking, fluency (number of responses), flexibility (differing responses), originality (unusual ideas), and elaboration (developing ideas). Shively (2011) embraces Guilford's FFOE model, believing that shared vocabulary gives children the language needed to become meta-cognitive about creativity and communicate creative ideas. Although widely used as a creativity test and reported to predict adult creative achievement (Millar, Dahl, \& Kauffman, 2011), the TTCT are limited by a focus on divergent thinking, a lack of content area assessment (Sawyer, 2010), and the extensive administration and scoring training required (Baldwin, 2010).

Other creativity assessments and programs have been developed; however, no single test or program has demonstrated increased creative ability or predicted, with certainty, real-life creative production. Creative achievement includes complex interactions using convergent and divergent thinking throughout creative processes (Sawyer, 2006). A review of creativity literature reveals that relationships between IQ (intelligence quotient), which may account for less than 10 percent of career success (Millar \& Dahl, 2011), and CQ (creativity quotient) have not been fully explicated, partly because creativity is shaped within context and partly because obvious challenges exist measuring such divergent concepts (Batey \& Furnham, 2006). Research contends that creativity is multi-faceted and requires multi-method research designs.

\section{Reflecting on the Creativity Literature}

Our review of the literature suggests that current thinking about creativity is rooted within individual constructs. Clearly, a Western/European bias toward 
individual, loner, eminent, genius, fine art creativity permeates creativity research and influences what creativity is perceived to be, especially in the mirror Henry (1964) holds up to Western schooling.

Perhaps our critique of creativity research might help others understand it better. For example, if we treat creative people like odd, disruptive individuals whose creative actions differ from curriculum goals, our hopes of working with children to celebrate diversity in hospitable ways might never be realized. As idealistic as it may sound, we believe educational communities can embrace and celebrate human differences. We believe teachers should aspire to idealistic, even utopian, standards that inspire children to celebrate diversity.

It interests us that creativity is often described as complex and divergent-a construct that educators simply have difficulty comprehending. Any haphazard, serendipitous poking around on YouTube suggests that creative displays are far from odd, rare, or complex. The range of creative endeavors humans engage in and share is rich and varied, living alongside schooling but seeming not to influence schooling in powerful ways.

Is it possible that creativity is less complex and more pervasive than we envision? Do we envision it as rare and complex because we see it through a tradition that carries norms of homogenization and compliance? Do we turn an unconsciously blind eye to rich creative experiences all around us because of the hegemony of a dominant liberal culture? Are we like aviators who crash in the desert and starve, unable to see plentiful-but uncommon to their experience-food around them?

\section{Unraveling the Individualistic View of Creativity}

Our thinking about creativity aligns with Howard Gardner's (1983) work; he believes creativity is a kind of intelligence people use naturally. Gardner lists eight "intelligences" in his seminal book, Frames of Mind. Two are highly privileged in schools-linguistic intelligence (reading, writing, and speaking) and logical-mathematical intelligence (reasoning, calculating, and experimenting). Gardner's lessknown intelligences include spatial (imagining, drawing, designing), bodily-kinesthetic (crafting, acting, displaying physical abilities), musical (listening, composing, playing instruments), interpersonal (empathizing, negotiating, cooperating), intrapersonal (self-understanding, reflecting, feeling), and naturalist intelligences (discriminating, classifying, nurturing living things). 
All these intelligences are creative; however, students who speak, write, or reason well are rewarded in schools. Perhaps even more creative children-who see things as pictures, not words, experience things physically-are disadvantaged. Teachers believe they value creativity but have limited ideas about creativity (Skiba, Tan, Sternberg, \& Grigorenko, 2010) and seldom appreciate behaviors associated with creativity-disruptiveness, nonconformity, and impulsivity (Cropley \& Cropley, 2009; Kaufman 2009). Teachers, often cultured not to prize creative but off-curricular activities, seldom move past standardized curriculum. Who can blame them? The curriculum is sanctioned powerfully and legally into their work. Unfortunately, exceedingly creative children may be labeled learning disabled, ADD (attention deficit disorder), or even autistic. As Henry (1964) implies, school seldom makes life easy for non-traditional students.

Exploring Compliant Acquiescent Disorder (CAD), Westheimer (2010) highlights the acceptance of increased medicalization of youth based on authoritarian relationships. He defines CAD as people failing to be outraged when outrage is needed and notes that student compliance is so expected that anything else represents ODD (Operational Defiance Disorder) and is treated by medication. Kaufman (2009) discusses "mad" genius mythologies, noting that hearsay, inconclusive research, and reliance on anecdotal evidence fuels erroneous connections between mental illness and creativity. Such mythologies prevail as we diagnose illnesses to explain why some children don't fit school. Rather than spreading anxiety, fear, shame, or superiority among children and parents by testing to discover what's wrong with or unusual about kids, we should be asking: What is right with kids? What would schools that fit all children look like?

As seemingly divergent as creativity is thought to be and despite research findings dispelling creativity mythologies, the image of society's solitary eccentricsthe "mad genius" or "tormented artist" (Kaufman, 2009) who lives on the margins of society's accepted behaviors-prevails. These definitions seem to share an uncritically individualistic view of creativity. Thus, schools remain institutions where creativity is limited to lone pursuits acceptable only in certain subjects, and creative behaviors are seen as blocking education's smooth workings, which we critique as centered upon all children doing similar things at similar times.

\section{Exploring the Ecology of Creativity}

As mentioned, we believe an ecological perspective holds promise for infusing creativity into children's lives. Renowned psychologist Bronfenbrenner (1981) 
pioneered the field of human ecology - "the social fabric that nurtures and sustains our capacity to live and work together effectively and to raise our children to become competent and compassionate members of society" (p. 38). Bronfenbrenner's (2005) bioecological model illustrates his theory that humans live within a set of systems similar to nested Russian dolls. Individuals influence, and are influenced by, an everwidening circle of systems. Bronfenbrenner proposes that family, peers, neighborhood, and school (micro-system) and the reciprocal relationships (mesosytem) that develop between them profoundly affect children's social, psychological, and behavioral development. A child's ever-expanding world - the community (exosystem) and cultural forces (macrosystem), bounded by multiple dimensions of time (chronosystem) - creates further opportunities for reciprocal influences between the systems.

Bronfenbrenner believes, "Every child needs at least one adult who is irrationally crazy about him or her" (Brendtro, 2006, p. 165). To flourish and develop as creative individuals, children must be surrounded by adults who unconditionally accept them, believe in their creative potential, and-with wild abandon-capably model creativity. Creativity is nurtured through harmonious, multi-directional relationships - the social fabric of our lives. Opportunities to nurture creativity begin before birth and continue throughout childhood, adulthood, and the twilight years.

Contrary to the belief that creative people are loners, children from larger families are generally accepted to be more creative, possibly because of less parental supervision and more opportunity for group interaction and imaginative play. Like the Brontes, children who develop imaginary friends or invent imaginary worlds (paracosms) are often more creative. Creative children also tend to be contrarian, which might explain why teachers find them challenging to work with in classroom settings designed for compliance. Conformity does not encourage the kind of creativity we advocate.

We believe creativity is enhanced through sharing dialogic spaces. Russian philosopher Bakhtin (1981), a pioneer of dialogic theory, posited that written and spoken languages carry history and the values of the speaker. Reflective and collective meaning making in Bakhtin's conception of dialogic occur through interactions with others and with self; past dialogues merge with the present to shape the future. Such is the creative path.

Education is essentially a dialogic experience; teachers and students infuse personal histories into a space already permeated with others' historical views. Through dialogical interactions, thoughts and ideas are explored and evaluated in 
the present and extended into the future. Bakhtin encouraged us to live dialogically, "as one who is evolving and developing, a person who learns from life" (p. 10). In his book, Mind Expanding: Teaching for Thinking and Creativity in Primary Education, Wegerif (2010) advises: "Teaching for thinking, creativity and learning is hard because it requires that the teacher also has to think seriously about things, respond creatively to events and love to learn" (p. 131). "Successful teaching for thinking ... is more centrally about the quality of relationships and about drawing children into dialogue" (p. 141).

By thoughtfully designing school environments and working in a spirit of collaboration and acceptance, schools can become creative learning spaces.

\section{Creativity and Digital Technologies}

The strong call for creativity in 21 st century literacy, along with a push to utilize technology more fully in schools, is challenging because it seems market driven, aimed at economic prosperity perhaps more than doing what's best for children in schools. Questions arise about technology: Does technology actually help or hinder creativity? Is the push to use more technology driven by sound educational research or corporate consumerism? Do the demands of technology on teachers (searching for information, designing and preparing print and digital materials, completing forms, communicating with stakeholders) steal time from meaningful interactions with children and the deep pondering critical to understanding each student's learning needs?

In a 2011 public lecture in Edmonton, MIT Professor Sherry Turkle (Alone Together: Why We expect More from Technology and Less from Each Other), notes that in the 1970s she and other MIT researchers explored tasks that might keep computers busy such as preparing taxes, academic writing, and games. However, suggests Turkle, the tables have turned and computers now keep us busy: "It is as though we are their killer app" (Gariépy, 2011, p. 6).

When technology supports curriculum, and is not curriculum itself, many dynamic, diverse, and delightfully disorderly ways creatively engage children in learning. However, we worry that technology has become so elegant and accessible that it steals time from other tools of creativity-drawing, painting, sculpting, constructing, playing, dialoguing, daydreaming, and exploring. We are concerned about questionable educational practices: students cutting and pasting others' work, infringing on copyrights; slideshow presentation software used to write essays, confusing flashy for 
insightful; interactive white boards (IWB) used as lecture tools; and the proliferation of fancy, time-consuming applications that do not support meaningful learning.

Technology changes how children play. Advanced technology toys make the sounds, play the tunes, do the talking-all different from children who create their own universes-as we noted about the Brontes' toy soldiers and the imagination involved in playing with them. Do built-in bells and whistles cannibalize mindful activities - creating actions, feelings, responses, and imaginary worlds - that emerge because older toys don't do things? Are imaginary worlds becoming less common or simply changing based on available tools?

We are also concerned about the effects of communication technologies and virtual worlds on interpersonal relationships. A June 2011 Angus Reid poll indicated: "More than one third (38\%) of our members find people talking on a cell phone loudly very annoying." Our own observations suggest that individuals commonly participate in digital and virtual interactions at the expense of face-to-face relations. Is the promise of minimized communication with multiple users in digital spaces satisfying? An analysis of over 19 million Twitter accounts revealed, "only 21 percent of Twitter users are actual True Twitter Users," defined as a user who has tweeted at least 10 times, follows at least 10 people, and has at least 10 followers (Barracuda Labs, 2010). Because technological formats shape language, do abbreviated tweets, text messages, suspended face-to-face conversations, and enticing virtual worlds diminish the art of conversation and inhibit the growth of personal relationships vital to creative development.

It would also seem a loss to us if emerging personalized education results in computers assuming the teacher's role. The Internet abounds with applicationsoften intuitive software, adapting to skill levels and providing mini-tutorials - to teach and practice skills aimed at standardized test achievement. Although the Alberta Teachers Association (ATA) does not support the use of private, for-profit sites, schools worldwide subscribe, driven by high-stakes exam practice. We believe technology carries potential to support a balance between skill practice and inquiry experiences. We see unexplored creative potential for sharing technology spaces, working in groups. Technology integration requires thoughtful partnering with children as active participants in rich learning experiences.

Research suggests that technology is better used to support curriculum than be the curriculum (Parsons, McRae, \& Taylor, 2006). What hidden (Longstreet \& Shane, 1993) or null (Eisner, 1994) curriculum surrounds technology integration? 
Where will our relationships with and through technology lead? How is our creative potential affected by technology? Does technology control us or do we control it?

\section{Designing Spaces Where Creativity Flourishes}

For many reasons, some intentional and others accidental, education has been structured around a system of individualism-standardized testing, teacher accountability, grades, rewards, surveillance, competition, evaluation, and hierarchies of power that destroy intrinsic motivation and creativity (Hennessey, 2010). The current emphasis on standardized tests and acquisition of 21 st century skills, to get ahead, have created angst for teachers ensnared in a dichotomy between their professional insights about how best to support children's learning and the constraints of historical educational trappings.

Although our notion of what it means to be educated and how we educate children requires serious consideration beyond this paper, this discussion is crucial to deciding how we build creativity into curriculum. Here, we use a human ecological perspective to consider spaces that create fertile conditions for nurturing creativity. Our intent is not to provide a creativity recipe or formula, but to inspire change. We are interested in finding new ways for teachers and students to live together in the world by creating educational spaces based on dialogic relationships and respect for ourselves, others, and nature.

We need a new vision of learning places as creativity enabling spaces. In these spaces, children form positive connections and relationships with other learners; opportunities abound for play and imagination; critical, evaluative, and creative thinking are practiced; problem finding is as essential as problem solving; multiple perspectives trump right answers; content is integrated across subject areas; questions are encouraged and honored; passion, curiosity, wonder, awe, and serendipity abound; and learning is negotiated through respectful, free-flowing dialogue. Teachers are not gatekeepers or knowledge purveyors, but can learn alongside students as they provide expertise, guidance, and opportunities-ever mindful of the seriousness of their responsibilities and need to be continually guided by wisdom (Craft, 2010).

This optimistic vision leaves us with a question: How do teachers design for creativity in practical ways? Undoubtedly, the first step is to consider our attitudes and beliefs about creativity. Children sense real. They know if diversity and creativity are appreciated and if they, as individuals, are valued and respected. Teachers must 
value and model creativity (Dollinger, Burke, \& Gump, 2007), be open to experiences (Kaufman, 2009), and committed to doing what is best for children. They must be flexible, energetic, enthusiastic, knowledgeable, passionate about learning, and adept at research-based pedagogical methodologies (Renzulli \& De Wet, 2010). In other words, teachers must demonstrate the knowledge, skills, and attributes expected of them as professionals.

However, knowing and acquiring skills does not ensure that teachers will use these abilities to enhance creativity in their classrooms. Another layer must be addressed; teachers need to model and encourage qualities of humanness-acceptance, kindness, empathy, tolerance, inclusivity, diversity, connection, self-expression, humility, and respectfulness-within themselves and their students. The learning space must feel safe to all students; it should invite experimentation, risk-taking, mistakes, multiple perspectives, and conflict resolution. Richards (2010) reminds us that children should feel free to "be themselves, get involved, take a chance, be wrong, act a little strange without censure ... and display their all-too-eager enthusiasm" and teachers must learn to "cherish diversity ... to value the unique and shiny pieces of the mosaic they represent while also developing the overall picture" (pp. 217-219, 224).

As the Pearce writing suggests at the beginning of this paper, strong evidence exists that creativity flourishes through intrinsic motivation across all age groups (Hennessey, 2010; Kasof, Chen, Himsel, \& Greenberger, 2007). Why are external reward systems (prizes, competition, and high-stakes testing) commonly used to motivate students to perform, produce, and behave? Appearing to work in the short term and effective when expecting right answers (Hennessey, 2010), external rewards seldom have lasting effects. They inhibit people from experiencing flow state described by renowned creativity researcher Mihalyi Csikszentmihalyi (2008), in his seminal Flow: the Psychology of Optimal Experience as peak performance; individuals become so absorbed in creative pursuits that time stands still and personal cares and distractions fade away.

Although highly desirable for enabling creativity, intrinsic motivation can be elusive-especially for children shaped by external rewards. Intrinsic motivation finds enjoyment learning through self-direction, independence, collegial interactions, active engagement, individual choice (Hennessey, 2010), and group negotiations. Intrinsic motivation requires attention and hard work; it is a growth process encouraged by enabling children to self-monitor, regulate their attitudes and behaviors, and evaluate the ideas and products they generate. Intrinsic motivation and personal growth flourish when children feel learning is being done with them, not to 
them. Schools should be spaces were creativity is intrinsically motivated and peak performance follows authentic engagement in collaborative pursuits driven by the learners' interests and passions.

How do we help children develop intrinsic motivation? Children develop intrinsic motivation as they come to know themselves. Through dialogic interactions with self and others, children learn to engage in the inner dialogue and creative self-discovery that resulted in the Bronte children's imaginary worlds. Children need many opportunities to explore ideas with others; dialogue around quality literature; journal about wonderings, curiosities, insights, and questions; and practice respectful communication. Exploring innovative ways to share ideas and understandings reduces the monotony of projects, presentations, and displays that all turn out the same. Lines that delineate subjects must be smudged to help children see connections across subject areas. When children are offered ideas, encouragement, and open-ended inquiries, endless possibilities invite engagement and enrich learning.

How do we design creative physical spaces? Learning spaces, resource-rich artifacts, print materials, digital media, playthings, tools, and materials invite exploration and engagement. Group and individual workspaces that support collaboration and enable reflection (Fairweather $\&$ Cramond, 2010) are designed and rearranged by student needs. Here, multiple layers abound; the physical environment extends beyond classrooms into community, nature, and world. Abundant opportunities for interactions with others-field and subject experts, artistic and cultural experiences, and real-world engagements-expose children to what is and what can be. Outdoor experiences allow space for children to slow down, observe, and be inspired by nature's intricacies. These experiences rouse possibility thinking (Craft, 2010) and nurture creativity by revealing dynamic, diverse, and disorderly landscapes inherent in our physical, social, cultural, and ecological world.

\section{Summary and Final Thoughts}

Creativity research has historically been divided into two distinct approaches, cognitive and social; and four categories commonly known as P's-Person, Process, Product, and Press (Gangadharbatla, 2010), with two additional P's-Phase and Problem-added by Cropley and Cropley (2009). Alternatively, Csikszentmihalyi's (1999) systems theory, a convergence model of multiple components (systems), focuses on interactions among individuals (persons), domain (culture) and field (society/gatekeepers). For Csikszentmihalyi, creativity is the process of altering memes, the tiny components of domain handed down from former generations. Gangadharbatla 
(2010) believes technology should be an additional separate component of Csikszentmihalyi's systems as "technology is a defining feature of the human condition" (p. 225). Peppler and Solomou (2011) note that the expert panel (field) that gatekeeps the domain in the systems model is not as relevant in social media where members monitor contributions and creative ideas spread via dialogue.

We agree with the community-based foundation of Csikszentmihalyi's (1999) work. We believe, as he, that dialogue can powerfully blend creativity into schools. The role of dialogue in opening spaces informed by the historical beliefs and values inherent in written and spoken languages is a central theme of Bakhtin's (1981) dialogic theory. If we accept history influences our creativity dialogue, we no longer need to emphasize the novel or complex; we can free ourselves to see the bits, pieces, and sparks of creativity contained within the whole. Perhaps then we will be more open to seeing and celebrating creativity and determined to design creative, ecological, learning spaces, in the spirit of Bronfenbrenner (2005), where all individuals feel accepted and valued.

Because education addresses the whole child; nurtures future citizens; and is concerned with developing inclusive, engaging, and technologically supported learning environments, making good sense of research findings should be important to educators. Education can facilitate change and renew creative dimensions within our educative experiences; or, possibly erode emphases that already exist. How can we creatively work within education to edify society? Our research review raises many questions and confirms that more research is needed to inform and facilitate creativity-based educative experiences.

\section{Implications for Further Research}

Cropley and Cropley (2009) see "widespread agreement that the world needs novelty, change, and innovation" (p. 2). Given movement towards agreement on a definition and the advent of multidisciplinary approaches, an exciting era for creativity research unfolds. Notably, we need a definition of creativity hospitable to a maximum number of creative expressions; that definition might work best if it has a hard shell outside with a soft, gooey inside.

More research is needed into individual characteristics that influence creative performance; influences of gender, age, family, culture, society, and socio-economic status; correlations/fluctuations of IQ and CQ (Kaufman, 2009); bidirectional relationships between health and creativity (Runco, 2007); creativity assessments; 
and technologies. As educators, we urgently need research into innovative educational practices that nurture creativity in children to prepare them for adulthood in $a$ fast-paced, competitive, global community.

This phrase is italicized because, while commonly trotted out as a rationale for bridging creativity into our curricula, we have issues accepting the philosophy embedded within it. We must be careful not to accept unconsidered mythologies that drive us toward particular aims - as we suggested with a belief that creativity resides within odd individuals. We must generously and humbly-and dare we say creatively-challenge educational models that already exist within the goals we seek. We believe we can see and use creativity to revivify the imaginative creation of worlds, ideas, and possibilities that offer a balm to what we see as stultifying aspects of education that render the curriculum inhospitable to many children-those that Howard Gardner suggests do not measure up to the two most oft-used indicators of school success-written literacy and logical/rational thinking.

Educators must build broader curricula that encourage all children to think outside the box. As cliché as it sounds, thinking outside the box holds the possibility of creating new boxes with all the walls that make boxes both useful and limiting. How do we, as educators, eradicate our own narrowness and push ourselves towards a new way of exploring possibilities? How can we challenge the pedagogy and content of the curriculum and use our challenges to call for more rather than less creativity? We don't want kids to fit into the educational bog — we want them to lead us out of it.

\section{References}

Armstrong, T. (2007). The human odyssey: Navigating the twelve stages of life. New York: Sterling.

Bakhtin, M. (1981). The dialogic imagination. Austin, TX: University of Texas Press.

Baldwin, A. Y. (2010). Creativity: A look outside the box in classrooms. In R. A. Beghetto \& J. C. Kaufman (Eds.), Nurturing creativity in the classroom (pp. 73-87). New York: Cambridge University Press. http://dx.doi. org/10.1017/CBO9780511781629.005
Barracuda Labs 2009 Annual Report. (2010). Retrieved from http://barracudalabs. com/research_resources.html

Batey, M., \& Furnham, A. (2006). Creativity, intelligence, and personality: A critical review of the scattered literature. Genetic, Social, and General Psychology Monographs, 132(4), 355-429. Retrieved from http:// web.ebscohost.com.login.ezproxy. library.ualberta.ca/ehost/pdfviewer/ pdfviewer?sid=88c85038-5102-497db8ea-ac03033114e6\%40sessionmgr11\&vi $\mathrm{d}=2 \& \mathrm{hid}=10$ 
Brendtro, L. K. (2006). The vision of Urie Bronfenbrenner: Adults who are crazy about kids. Reclaiming Children \& Youth, 15(3), 162-166. Retrieved from http://search. ebscohost.com/login.aspx?direct=true\& $\mathrm{db}=$ ehh\&AN=23275096\&loginpage $=$ Lo gin.asp\&site $=$ ehost-live $\&$ scope $=$ site

Bronfenbrenner, U. (1981). Children and families: 1984? Society, 18(2), 38-41. Retrieved from http://www.springerlink.com.login. ezproxy.library.ualberta.ca/content/ kg00752211hl82g1/fulltext.pdf

Bronfenbrenner, U. (2005). Making human beings human: Bioecological perspectives on human development. Thousand Oaks, CA: Sage.

Craft, A. (2010). Possibility thinking and wise creativity: Educational futures in England? In R. A. Beghetto \& J. C. Kaufman (Eds.), Nurturing creativity in the classroom (pp. 289-312). New York: Cambridge University Press.

Cropley, A., \& Cropley, D. (2009). Fostering creativity: A diagnostic approach for higher education and organizations. Cresskill, NJ: Hampton Press.

Csikszentmihalyi, M. (1999). Implications of a systems perspective. In R. J. Sternberg (Ed.), Handbook of creativity (pp. 313-335). Cambridge, UK: Cambridge University Press.

Csikszentmihalyi, M. (2008). Flow: The psychology of optimal experience. New York: HarperCollins.

Dollinger, S. J., Burke, P. A., \& Gump, N. W. (2007). Creativity and values. Creativity Research Journal, 19(2-3), 91-103. doi:10.1080/10400410701395028

Egan, T. M. (2005). Factors influencing individual creativity in the workplace: An examination of quantitative empirical research. Advances in Developing Human Resources, 7(2), 160-181. doi:10.1177/1523422305274527

Eisner, E. W. (1994). The educational imagination: On design and evaluation of school programs (3rd ed.). New York: Macmillan.

Emerson, R. W., Ferguson, A. R., \& Carr, J. F. (1987). The Essays of Ralph Waldo Emerson. Cambridge, MA: Belknap.
Fairweather, E., \& Cramond, B. (2010). Infusing creative and critical thinking into the curriculum together. In R. A. Beghetto \& J. C. Kaufman (Eds.), Nurturing creativity in the classroom (pp. 113-141). New York: Cambridge University Press. http://dx.doi. org/10.1017/CBO9780511781629.007

Gangadharbatla, H. (2010). Technology component: A modified systems approach to creative thought. Creativity Research Journal, 22(2), 219-227. doi:10.1080/1040 019.2010 .481539

Gardner, H. (1983) Frames of mind: The theory of multiple intelligences. New York: Basic Books.

Gariépy, R. (2011). Alone together: Is technology reshaping our human relationships? ATA News, 45(19). Retrieved from http://www.teachers.ab.ca/Publications/ ATA\%20News/Volume-45-2010-11/Num ber\%2019/Pages/Alone-together.aspx

Gladwell, M. (2008). Outliers: The story of success. New York: Little, Brown, \& Company.

Guilford, J. P. (1950). Creativity. American Psychologist, 5(9), 444-454. doi:10.1037/ a0023220

Guilford, J. P. (1967). The nature of human intelligence. New York: McGraw-Hill.

Hennessey, B. A. (2010). Intrinsic motivation and creativity in the classroom: Have we come full circle? In R. A. Beghetto \& J. C. Kaufman (Eds.), Nurturing creativity in the classroom (pp. 329-361). New York: Cambridge University Press.

Henry, J. (1964). Culture against man. New York: Random House.

Kasof, J., Chen, C., Himsel, A., \& Greenberger, E. (2007). Values and creativity. Creativity Research Journal, 19(2-3), 105-122. doi:10.1080/10400410701397164

Kaufman, J. (2009). Creativity 101. New York: Springer Publishing Company.

Leyva, R. (2009). No Child Left Behind: A Neoliberal Repackaging of Social Darwinism. Journal for Critical Education Policy Studies, v7 n1, 364-381.

Longstreet, W. S., \& Shane, H. G. (1993). Curriculum for a new millennium. Boston: Allyn and Bacon. 
Millar, G., \& Dahl, C. (2011). The power of creativity. ATA Magazine, 9(3). Retrieved from http://www.teachers.ab.ca/Publications/ ATA\%20Magazine/Volume-91/Number3/ Pages/Thepowerofcreativity.aspx

Millar, G., Dahl, C., \& Kauffman, J. (2011). Testing the whole mind - educating the whole child. ATA Magazine, 9(3). Retrieved from http://www.teachers.ab.ca/Publications/ ATA\%20Magazine/Volume-91/Number3/ Pages/Thepowerofcreativity.aspx

Parsons, J. McRae, P., \& Taylor, L. (2006). Celebrating school improvement: Six lessons from Alberta's AISI projects. Edmonton: School Improvement Press.

Pearce, J.C. (1985). Magical child matures. New York: Dutton.

Peppler, K. A., \& Solomou, M. (2011). Building creativity: Collaborative learning and creativity in social media environments. On the Horizon, 19(1), 13-23. doi:10.1108/10748121111107672

Plucker, J. A., Beghetto, R. A., \& Dow, G. T. (2004). Why isn't creativity more important to educational psychologists? Potentials, pitfalls, and future directions in creativity research. Educational Psychologist, 39(2), 83-96. Retrieved from http://web.ebscohost.com.login.ezproxy. library.ualberta.ca/ehost/pdfviewer/ pdfviewer?sid=21cf8785-b93a-4f449690-8a90b9ccbcc8\%40sessionmgr14\&v id $=2 \&$ hid $=18$

Renzulli, J. S., \& De Wet, C. F. (2010). Developing creative productivity in young people through the pursuit of ideal acts of learning. In R. A. Beghetto \& J. C. Kaufman (Eds.), Nurturing creativity in the classroom (pp. 24-72). New York: Cambridge University Press. http://dx.doi.org/10.1017/ CBO9780511781629
Richards, R. (2010). Everyday creativity in the classroom: A trip through time with seven suggestions. In R. A. Beghetto \& J. C. Kaufman (Eds.), Nurturing creativity in the classroom (pp. 206-234). New York: Cambridge University Press.

Runco, M. A. (2007). Creativity theories and themes: Research, development, and practice. Burlington, MA: Elsevier Academic Press.

Sawyer, R. K. (2006). Explaining creativity: The science of human innovation. New York: Oxford.

Sawyer, R. K. (2010). Learning for Creativity. In R. A. Beghetto \& J. C. Kaufman (Eds.), Nurturing creativity in the classroom (pp. 172-190). New York: Cambridge University Press.

Shively, C. H. (2011). Grow creativity! Learning \& Leading with Technology, 38(7), 10-15.

Skiba, T., Tan, M., Sternberg, R. J., \& Grigorenko, E. L. (2010). Roads not taken, new roads to take: Looking for creativity in the classroom. In R. A. Beghetto \& J. C. Kaufman (Eds.), Nurturing creativity in the classroom (pp. 252-269). New York: Cambridge University Press.

Walker, E., Tabone, C., \& Weltsek, G. (2011). When Achievement Data Meet Drama and Arts Integration. Language Arts, 88(5), 365-372.

Wegerif, R. (2010). Mind expanding: Teaching for thinking and creativity in primary education. Berkshire, England: Open University Press.

Westheimer, J. (2010, August 11). Taking teaching to the edges (of the classroom) and beyond, Keynote at Telus Centre Auditorium, University of Alberta. 


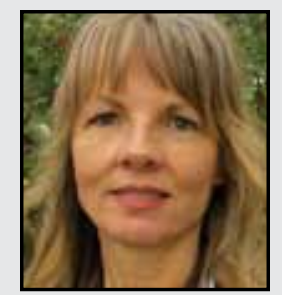

Maxine Sprague has over 15 years of teaching and shared leadership experience. She recently completed her Master of Education in Educational Studies degree with Honors at the University of Alberta. Maxine received the 2011 Junior Achievement Educator of the Year Award for her work in developing students' financial literacy through small business start-ups. Her interests include inquiry-based learning, digital technologies, creativity and innovation, human ecology, and sustainable living.

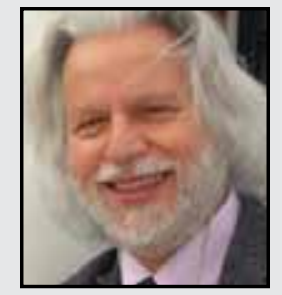

Jim Parsons has been a professor in the Department of Secondary Education since 1976. He teaches social studies education and research design. His recent work has been in the areas of teacher education, student engagement, and instructional leadership. 